\title{
Protocol
}

\section{Whole-Genome Sequencing: Manual Library Preparation}

\author{
Elaine Mardis and W. Richard McCombie
}

This protocol describes a manual approach for the preparation of genomic DNA libraries suitable for Illumina sequencing. Genomic DNA fragments produced by shearing by sonication are ligated to adaptors and amplified by polymerase chain reaction (PCR). The amplified DNA, separated by size and gel-purified, is suitable for use as template in whole-genome sequencing.

\section{MATERIALS}

$\stackrel{\infty}{\circ}$ Reagents

Acrylamide gels, precast (Life Technologies)

dATP $(1 \mathrm{~mm})$

DNA 1000 reagents (Agilent)

DNA ladder (50-bp) (TrackIt; Life Technologies)

DNA ladder (100-bp) (New England Biolabs)

DNA Terminator End Repair Kit (Lucigen)

Ethanol (70\% and 100\%)

FlashGel DNA cassette $(2.2 \%, 12+1$ well) (Lonza)

FlashGel DNA marker (50-bp to 1.5-kb) (Lonza)

FlashGel loading dye (Lonza)

Gel-loading buffer with bromophenol blue (10x)

Genomic DNA

GlycoBlue (15 mg/mL) (Ambion)

Klenow fragment exonuclease (New England Biolabs)

MinElute PCR Purification Kit (QIAGEN)

$\mathrm{NaCl}(400 \mathrm{~mm})$

Paired-end (PE) forked adaptor duplex ( $4 \mu \mathrm{M})$ (Illumina, Sigma-Aldrich)

PE PCR Primer 1.0 (8 $\mu \mathrm{M})$ (HPLC purification, 100-nm scale; IDT):

A^ATGATACGGCGACCACCGAGATCTACACTCTTTCCCTACACGACGCTCTTCCGATCT

PE PCR Primer $2.0(8 \mu \mathrm{M})$ (HPLC purification, 100-nm scale; IDT):

$\mathrm{C}^{\star A A G C A G A A G A C G G C A T A C G A G A T C G G T C T C G G C A T T C C T G C T G A A C C G C T C T T C C ~}$ GATCT

From the Molecular Cloning collection, edited by Michael R. Green and Joseph Sambrook. 
Phusion High-Fidelity PCR Master Mix with HF Buffer $(2 \times)$ (New England Biolabs) Quant-iT dsDNA High Sensitivity Assay Kit and/or Qubit BR Assay Kit (Life Technologies) Quick Ligation Kit (New England Biolabs)

SYBR Green I nucleic acid gel stain (Life Technologies)

TBE buffer $<\mathrm{R}>$

TBE gel (Novex 4\%-12\%, 1.0-mm×12-well) (Life Technologies)

Equipment

DNA 1000 chips and analyzer (Agilent)

Fluorometer (e.g., Qubit; Life Technologies)

HV DuraPore filter columns $(0.4-\mu \mathrm{m})$ (Millipore)

Microcentrifuge tubes $(0.2-\mathrm{mL}$ and $1.7-\mathrm{mL})$

microTube $(6 \times 16-\mathrm{mm})$, with AFA fiber and Snap-Cap (Covaris)

microTube holder (Covaris)

Sonicator (Covaris)

XCell SureLock Mini-Cell (Life Technologies)

METHOD

Library Sonication and End Repair

1. Prepare a sample of $100 \mathrm{ng}, 500 \mathrm{ng}, 1 \mu \mathrm{g}$, or $3 \mu \mathrm{g}$ of genomic DNA.

2. Dilute the DNA in a $1.7-\mathrm{mL}$ tube, as follows:

End repair buffer $(5 \times)$

DNA sample

$\mathrm{H}_{2} \mathrm{O}$

$x \mu \mathrm{L}$

Total volume

$(40-x) \mu \mathrm{L}$

$50 \mu \mathrm{L}$

Vortex the tube for $1-2 \mathrm{sec}$. Centrifuge the tube for $5 \mathrm{sec}$.

3. Transfer the diluted DNA to a Covaris sample vessel. Centrifuge the vessel to ensure that there are no bubbles in solution.

4. Sonicate the sample according to the manufacturer's instructions.

Provide your desired fragment size to determine the proper program to use.

5. After shearing the DNA, remove the sample vessel from the water bath. Centrifuge to collect the sample at the bottom of the vessel.

6. Add $2 \mu \mathrm{L}$ of End repair enzyme mix to the sample vessel. Vortex lightly to mix, and centrifuge briefly. Incubate the reaction for $30 \mathrm{~min}$ at room temperature.

7. Combine the $50-\mu \mathrm{L}$ reaction and $250 \mu \mathrm{L}$ of Buffer PB or PBI in a $1.7-\mathrm{mL}$ tube. Vortex the tube.

8. Purify the DNA using a MinElute column, as follows.

i. Add the reaction/buffer mix to a MinElute column. Centrifuge the column at $14,000 \mathrm{~g}$ for 1 min or place on a vacuum manifold and draw the liquid through the column.

ii. Dispose of waste if the tube was centrifuged.

iii. Add $750 \mu \mathrm{L}$ of Buffer PE. Centrifuge the column at 14,000 $\mathrm{g}$ for $1 \mathrm{~min}$ or place on a vacuum manifold and draw the liquid through the column.

iv. Dispose of waste if the tube was centrifuged.

v. Add $750 \mu \mathrm{L}$ of Buffer PE. Centrifuge the column at $14,000 \mathrm{~g}$ for $1 \mathrm{~min}$ or place on a vacuum manifold and draw the liquid through the column. 
E. Mardis and W.R. McCombie

vi. Dispose of waste if the tube was centrifuged. If using a vacuum manifold, place the column in a waste collecting tube, and centrifuge the column at 14,000 $\mathrm{g}$ for $1 \mathrm{~min}$.

vii. Rotate the tube $180^{\circ}$. Centrifuge the column at $14,000 \mathrm{~g}$ for $1 \mathrm{~min}$.

viii. Dispose of the waste tube.

ix. Transfer the column to a $1.7-\mathrm{mL}$ tube.

x. Add $16 \mu \mathrm{L}$ of Buffer $\mathrm{EB}$ to the column, and incubate it for $1 \mathrm{~min}$ at room temperature. Centrifuge the column at $14,000 \mathrm{~g}$ for $1 \mathrm{~min}$.

xi. If necessary, add another $16 \mu \mathrm{L}$ of Buffer EB to the column, and incubate it for $1 \mathrm{~min}$ at room temperature. Centrifuge the column at $14,000 \mathrm{~g}$ for $1 \mathrm{~min}$.

Two elutions are necessary only if a large amount of DNA was sonicated (e.g., for $3 \mu \mathrm{g}$ of input DNA).

xii. Discard the column, and transfer the sample to a $0.2-\mathrm{mL}$ PCR tube.

3' Adenylation (A-Tailing)

9. Set up the A-tailing reaction using the purified DNA from Step 8.xii.

$\begin{array}{lr}\text { Purified end repair DNA } & 32 \mu \mathrm{L} \\ \text { Klenow buffer }(10 \times) & 5 \mu \mathrm{L} \\ \text { dATP }(1.0 \mathrm{~mm}) & 10 \mu \mathrm{L} \\ \text { Klenow exonuclease }(5 \mathrm{U} / \mu \mathrm{L}) & 3 \mu \mathrm{L} \\ \text { Total volume } & 50 \mu \mathrm{L}\end{array}$

Pipette up and down to mix, centrifuge briefly, and incubate the reaction for $30 \mathrm{~min}$ at $37^{\circ} \mathrm{C}$.

10. Combine the $50-\mu \mathrm{L}$ reaction and $250 \mu \mathrm{L}$ of Buffer PB or PBI in a $1.7-\mathrm{mL}$ tube. Vortex the tube.

11. Purify the DNA using a MinElute column by following Steps 8.i-8.xii, except alter the Buffer EB elution, using the values in the following table:

\begin{tabular}{lccc}
\hline \multicolumn{4}{c}{ Input } \\
\hline $100 \mathrm{ng}$ & $500 \mathrm{ng}$ & $1 \mu \mathrm{g}$ & $3 \mu \mathrm{g}$ \\
\hline $10 \mu \mathrm{L}$ twice & $10 \mu \mathrm{L}$ twice & $18 \mu \mathrm{L}$ twice & $18 \mu \mathrm{L}$ twice \\
\hline
\end{tabular}

Adaptor Ligation

12. Using the purified product from the A-tailing reaction (purified in Step 11), prepare the adaptor ligation reaction as follows:

\begin{tabular}{lcccc}
\hline & \multicolumn{4}{c}{ Input } \\
\cline { 2 - 5 } & $100 \mathrm{ng}$ & $500 \mathrm{ng}$ & $1 \mu \mathrm{g}$ & $3 \mu \mathrm{g}$ \\
\hline Purified A-tailed DNA & $20 \mu \mathrm{L}$ & $20 \mu \mathrm{L}$ & $20 \mu \mathrm{L}$ & $20 \mu \mathrm{L}$ \\
PE forked adaptor duplex & $1.0 \mu \mathrm{L}$ & $2.5 \mu \mathrm{L}$ & $5.0 \mu \mathrm{L}$ & $7.0 \mu \mathrm{L}$ \\
$\mathrm{NEB}$ Quick Ligation Buffer $(2 \times)$ & $25 \mu \mathrm{L}$ & $25 \mu \mathrm{L}$ & $25 \mu \mathrm{L}$ & $25 \mu \mathrm{L}$ \\
$\mathrm{H}_{2} \mathrm{O}$ & $1.5 \mu \mathrm{L}$ & - & - & - \\
NEB Quick Ligase $(2000 \mathrm{U} / \mu \mathrm{L})$ & $2.5 \mu \mathrm{L}$ & $2.5 \mu \mathrm{L}$ & $2.5 \mu \mathrm{L}$ & $2.5 \mu \mathrm{L}$ \\
Total volume & $50 \mu \mathrm{L}$ & $50 \mu \mathrm{L}$ & $52.5 \mu \mathrm{L}$ & $54.5 \mu \mathrm{L}$ \\
\hline
\end{tabular}

i. Combine the DNA and the adaptor in a tube. Pipette to mix. Centrifuge briefly.

ii. Add the $2 \times$ buffer and $\mathrm{H}_{2} \mathrm{O}$. Pipette to mix. Centrifuge briefly.

iii. Add the ligase. Pipette to mix. Centrifuge briefly.

iv. Incubate the reaction for $15 \mathrm{~min}$ at room temperature.

13. Purify the DNA using a MinElute column by following Steps 8.i-8.xii, except use $10 \mu \mathrm{L}$ of Buffer EB elution in Steps 8.x and 8.xi. 


\section{BOX 1. EXAMPLE CALCULATION FOR SAMPLE DILUTION}

The elution volume of the sample after quantitation is $10.5 \mu \mathrm{L}$. The DNA concentration is $21.6 \mathrm{ng} / \mu \mathrm{L}$. The initial library input was $500 \mathrm{ng}$; therefore, the DNA needs to be diluted to $10 \mathrm{ng} / \mathrm{\mu L}$. The following formula will provide the amount of Buffer EB to add to the sample to obtain a 10-ng/ $\mu \mathrm{L}$ sample:

Final volume $=(10.5 \mu \mathrm{L} \times 21.6 \mathrm{ng} / \mu \mathrm{L})(10 \mathrm{ng} / \mu \mathrm{L})=22.68 \mu \mathrm{L}$.

$22.68 \mu \mathrm{L}-10.5 \mu \mathrm{L}=12.18 \mu \mathrm{L} \approx 12.2 \mu \mathrm{L} \leftarrow$ Add this amount of Buffer EB to sample to dilute it to $10 \mathrm{ng} / \mu \mathrm{L}$.

14. Determine the concentration of the DNA by assaying $1 \mu \mathrm{L}$ of the DNA with the Quant-iT dsDNA HS Assay Kit (for 100-ng input) or the BR Assay Kit (for the others) and reading the results on a fluorometer. If the concentration of the recovered DNA is $>10 \mathrm{ng} / \mu \mathrm{L}$, dilute the sample with Buffer EB as follows:

\begin{tabular}{lr}
\hline Input DNA & Dilute to \\
\hline $100 \mathrm{ng}$ & $1 \mathrm{ng} / \mu \mathrm{L}$ \\
$500 \mathrm{ng}$ & $10 \mathrm{ng} / \mu \mathrm{L}$ \\
$1 \mu \mathrm{gg}$ & $10 \mathrm{ng} / \mu \mathrm{L}$ \\
$3 \mu \mathrm{g}$ & $10 \mathrm{ng} / \mu \mathrm{L}$ \\
\hline
\end{tabular}

An example calculation is provided in Box 1.

The yield of recovered ligated DNA should be $\geq 20 \%$, relative to the input DNA. For example, a 100-ng input library should generate $\geq 20$ ng of ligated DNA.

\section{PCR Cycle Optimization}

15. Set up one amplification reaction for each library construction reaction generated in $0.2-\mathrm{mL}$ PCR tubes. Irrespective of the number of samples used, perform only one negative control (Buffer EB instead of DNA). If desired, a master mix can be made without DNA and aliquoted into $0.2-\mathrm{mL}$ PCR tubes. Add $1 \mu \mathrm{L}$ of sample or Buffer EB (for negative control), then mix and centrifuge briefly.

Purified DNA sample from ligation (Step 13)

$1 \mu \mathrm{L}$

Phusion PCR master mix $(2 \times)$

$25 \mu \mathrm{L}$

PCR PE Primer $1.0(8 \mu \mathrm{M})$

$1 \mu \mathrm{L}$

PCR PE Primer $2.0(8 \mu \mathrm{M})$

$1 \mu \mathrm{L}$

$\mathrm{H}_{2} \mathrm{O}$

$22 \mu \mathrm{L}$

Total volume

$50 \mu \mathrm{L}$

Buffer EB

$1 \mu \mathrm{L}$

Phusion PCR master mix $(2 \times)$

$25 \mu \mathrm{L}$

PCR PE Primer $1.0(8 \mu \mathrm{M})$

$1 \mu \mathrm{L}$

PCR PE Primer $2.0(8 \mu \mathrm{M})$

$1 \mu \mathrm{L}$

$\mathrm{H}_{2} \mathrm{O}$

$22 \mu \mathrm{L}$

Total volume

$50 \mu \mathrm{L}$

16. Create two PCR programs.

\section{Program 1}

\begin{tabular}{llll}
\hline Cycle number & Denaturation & Annealing & Polymerization \\
\hline 1 & $30 \mathrm{sec}$ at $98^{\circ} \mathrm{C}$ & & \\
4 or 6 cycles & $10 \mathrm{sec}$ at $98^{\circ} \mathrm{C}$ & $30 \mathrm{sec}$ at $65^{\circ} \mathrm{C}$ & $30 \mathrm{sec}$ at $72^{\circ} \mathrm{C}$ \\
\hline${ }^{\mathrm{a}}$ Run 4 cycles for 10 -ng PCR or 6 cycles for 1 -ng PCR. & \\
Hold at $4^{\circ} \mathrm{C}$. & &
\end{tabular}


E. Mardis and W.R. McCombie

Program 2

\begin{tabular}{llll}
\hline Cycle number & Denaturation & Annealing & Polymerization \\
\hline 2 cycles & $10 \mathrm{sec}$ at $98^{\circ} \mathrm{C}$ & $30 \mathrm{sec}$ at $65^{\circ} \mathrm{C}$ & $30 \mathrm{sec}$ at $72^{\circ} \mathrm{C}$ \\
\hline Hold at $4^{\circ} \mathrm{C}$. & & &
\end{tabular}

17. Label a $0.2-\mathrm{mL}$ tube for the PCR negative control.

18. Label six 0.2-mL tubes.

for 1-ng PCR PCR-6, PCR-8, PCR-10, PCR-12, PCR-14, and PCR-16

for 10-ng PCR PCR-4, PCR-6, PCR-8, PCR-10, PCR-12, and PCR-14

19. Using the $50-\mu \mathrm{L}$ reaction(s) from Step 15 , run PCR Program 1 , and collect $5 \mu \mathrm{L}$ of the reaction in the $0.2-\mathrm{mL}$ tube labeled either PCR-6 (for 1-ng input) or PCR-4 (for 10-ng input).

20. Continue the PCR optimization by running PCR Program 2, and collect $5 \mu \mathrm{L}$ of the reaction in the second $0.2-\mathrm{mL}$ tube in the series.

21. Repeat Step 20 for the remaining four cycle-collection points.

22. Collect $5 \mu \mathrm{L}$ of the negative control at the final cycle-collection point.

23. Add $1 \mu \mathrm{L}$ of loading dye to each $5-\mu \mathrm{L}$ aliquot. Vortex quickly and centrifuge the tubes.

24. Prepare a 2.2\% FlashGel with $4 \mu \mathrm{L}$ of $\mathrm{H}_{2} \mathrm{O}$ in each of the 13 wells and $4 \mu \mathrm{L}$ of Flash 50- to 1500-bp gel marker in the seventh lane. Load (+) DNA reactions in Lanes 1-6 and 8-12 and (-) DNA reaction in Lane 13. A duplicate will not be needed for the final cycle run.

25. Load the 6- $\mu \mathrm{L}$ aliquots of DNA amplifications in Lanes 1-6 and 8-12. Load the negative control aliquot in Lane 13. Run the FlashGel for $7 \mathrm{~min}$ at $275 \mathrm{~V}$.

26. Photograph the gel. Identify cycles of overamplification. For the full-scale PCR (next section), use the greatest number of cycles that do not show overamplification.

For small insert libraries, 1.2\% FlashGels do not provide sufficient resolution to separate unused primer/ primer dimers, PE adaptor artifact, and PCR product smear. The use of 1.2\% DNA FlashGels should only be used when 2.2\% DNA FlashGels are unavailable.

PCR Amplification of Ligated Fragments

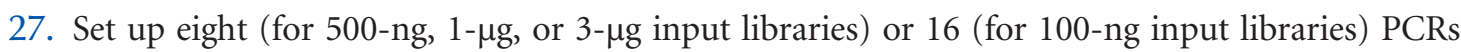
using purified sample from the adaptor ligation step (Step 13).

$\begin{array}{lr}\text { Adaptor ligated DNA }(10 \mathrm{ng} / \mu \mathrm{L}) & 1 \mu \mathrm{L} \\ \text { Phusion PCR Master Mix }(2 \times) & 25 \mu \mathrm{L} \\ \text { PE Primer } 1.0(8 \mu \mathrm{M}) & 1 \mu \mathrm{L} \\ \text { PE Primer 2.0 }(8 \mu \mathrm{M}) & 1 \mu \mathrm{L} \\ \mathrm{H}_{2} \mathrm{O} & 22 \mu \mathrm{L} \\ \text { Total } & 50 \mu \mathrm{L}\end{array}$

28. Program the thermal cycler based on the optimization results from the previous section.

\begin{tabular}{lccc}
\hline Cycle number & Denaturation & Annealing & Polymerization \\
\hline 1 & $30 \sec$ at $98^{\circ} \mathrm{C}$ & & \\
$N$ cycles & & \\
Last cycle & $10 \sec$ at $98^{\circ} \mathrm{C}$ & $30 \sec$ at $65^{\circ} \mathrm{C}$ & $30 \mathrm{sec}$ at $72^{\circ} \mathrm{C}$ \\
\hline Hold at $10^{\circ} \mathrm{C}$. & & $5 \mathrm{~min}$ at $72^{\circ} \mathrm{C}$ \\
\hline
\end{tabular}

29. Pool all of the PCRs. Combine the pooled DNA with 5 volumes of Buffer PBI in a 15-mL conical tube.

It might be necessary to add $5 \mu \mathrm{L}$ of $3 \mathrm{M}$ sodium acetate $(\mathrm{pH}$ 5.0) if the reaction/buffer mix has a violet tinge. 
30. Purify the amplified DNA using a MinElute column. Use one column for every eight PCRs that were run.

i. Add the reaction/buffer mix to the MinElute column(s). If loading two columns, split the mix as evenly as possible between the two columns.

ii. Centrifuge the column at $14,000 \mathrm{~g}$ for $1 \mathrm{~min}$ or place it on a vacuum manifold and draw the liquid through the column.

iii. Dispose of waste if the tube was centrifuged.

iv. Repeat Steps 30.i-30.iii until all of the reaction has been passed through the MinElute column $(\mathrm{s})$.

v. Wash the column(s) twice with $750 \mu \mathrm{L}$ of Buffer PE.

vi. If using a vacuum system, place the column in a waste collecting tube, and centrifuge the column at $14,000 \mathrm{~g}$ for $1 \mathrm{~min}$.

vii. Rotate the tube $180^{\circ}$. Centrifuge the column at $14,000 \mathrm{~g}$ for $1 \mathrm{~min}$.

viii. Discard the waste tube.

ix. Transfer the column to a $1.7-\mathrm{mL}$ tube.

x. Add $13 \mu \mathrm{L}$ of Buffer EB. Incubate for $1 \mathrm{~min}$ at room temperature.

xi. Centrifuge the column at $14,000 \mathrm{~g}$ for $1 \mathrm{~min}$.

xii. Run $1 \mu \mathrm{L}$ of sample on a 2.2\% FlashGel, and determine the DNA concentration using $1 \mu \mathrm{L}$ in a Qubit/Quant-iT dsDNA HS DNA assay.

Amplification should not require more than 12 cycles. Higher cycle numbers may result in a reduction in the number of unique sequence fragments. If too little ligation DNA was recovered or if too many PCR cycles are required for enrichment, then it may be necessary to prepare a fresh sample aliquot. Determine the sample availability or tolerance for lower percentage of unique fragments within the library before library construction.

\section{Size Selection}

31. Prepare an acrylamide gel made with TBE buffer.

32. Add $3 \mu \mathrm{L}$ of $10 \times$ Gel-loading buffer to the entire purified DNA sample $(\sim 10 \mu \mathrm{L})$.

33. Load the gel as follows:

\begin{tabular}{lll}
\hline Lane & Reagent & Amount \\
\hline Lane 1 & Gel-loading buffer (10x) & \\
Lane 2 & Lonza 50-1500-bp ladder & $5 \mu \mathrm{L}$ \\
Lane 3 & Tracklt 50-bp ladder & $5 \mu \mathrm{L}$ \\
Lane 4 & Empty & \\
Lane 5 & Sample & $500 \mathrm{ng}$ (all or half-1 $\mu$ g vs. 100 ng) \\
Lane 6 & Sample & $500 \mathrm{ng}$ (half [100 ng] of sample [15 $\mu \mathrm{L}]$ ) \\
Lane 7 & Empty & \\
Lane 8 & Tracklt 50-bp ladder & $5 \mu \mathrm{L}$ \\
Lane 9 & Lonza 50-1500-bp ladder & $5 \mu \mathrm{L}$ \\
Lane 10 & Gel-loading buffer (10x) & \\
\hline
\end{tabular}

Care should be taken not to overload the acrylamide gel lanes with excess PCR product. It is possible for high-abundance DNA fragments to migrate at incorrect sizes. For example, if too much 120-bp PE ligation artifact is loaded into a single lane, then it may be present in gel cuts $>120 \mathrm{bp}$.

Acrylamide gel loading is tricky. Diluting the PCR product 1:5 (5xdye:DNA) is likely to be insufficient for the sample to remain at the bottom of the well. Overloading the dye (1:1) seems to allow the sample to rest at the bottom of the well without negatively affecting the run. The larger the amount of DNA, the less dye is required for successful gel loading.

A small amount of DNA + dye (1-2 $\mu$ L) should be loaded to test whether the sample will rest at the bottom of the well. The end of the loading tip should be as low as possible in the well, and the sample should load 
E. Mardis and W.R. McCombie

around the tip. The tip should be slowly removed from the well without introducing an air bubble or dislodging the DNA + dye.

34. Run the gel at $180 \mathrm{~V}$ for $\sim 50 \mathrm{~min}$.

Gel Purification

35. Stain the gel in SYBR Green (diluted 1:10,000) for $10 \mathrm{~min}$.

36. Destain the gel in TBE buffer or $\mathrm{H}_{2} \mathrm{O}$ for 3 min.

37. Prepare one or two $0.7-\mathrm{mL}$ tubes for gel shredding by poking a needle through the bottom of the tube. Place each $0.7-\mathrm{mL}$ tube inside a $1.7-\mathrm{mL}$ tube.

38. Excise gel fragments at the desired size range, and place each gel slice in a $0.7-\mathrm{mL}$ tube. Cap and label the tubes.

39. Photograph the gel.

40. Centrifuge the $0.7-\mathrm{mL}$ tubes (within the $1.7-\mathrm{mL}$ tubes) at $14,000 \mathrm{rpm}$ for $5 \mathrm{~min}$.

41. Remove the $0.7-\mathrm{mL}$ tube. Verify that all of the gel has moved through the bottom of the tube. If not, centrifuge it again.

42. Add $400 \mu \mathrm{L}$ of $400 \mathrm{~mm} \mathrm{NaCl}$ to the sheared gel. Place the tube(s) on a shaker for at least $2 \mathrm{~h}$ (overnight is OK) to elute the DNA from the gel.

43. Using a wide-bore $200-\mu \mathrm{L}$ pipette tip, transfer all of the gel and solution to a $0.45-\mu \mathrm{m} \mathrm{HV}$ DuraPore filter column.

44. Centrifuge the solution through the filter at $14,000 \mathrm{rpm}$ for $5 \mathrm{~min}$.

45. Dispose of the column. Transfer the solution to a new $1.7-\mathrm{mL}$ tube.

46. Add $1 \mu \mathrm{L}$ of GlycoBlue reagent. Add $1 \mathrm{~mL}$ of ethanol. Incubate for $60 \mathrm{~min}$ at $-20^{\circ} \mathrm{C}$.

47. Centrifuge at $14,000 \mathrm{~g}$ for $30 \mathrm{~min}$.

48. Note the blue precipitate at the bottom of the tube. Remove the ethanol.

49. Add $1 \mathrm{~mL}$ of $70 \%$ ethanol. Centrifuge at $14,000 \mathrm{~g}$ for $15 \mathrm{~min}$.

50. Note the blue precipitate at the bottom of the tube. Remove the ethanol.

51. Repeat Steps 49 and 50.

52. Using a small pipette tip, carefully remove as much ethanol as possible. Centrifuge the tube briefly if necessary.

53. Air-dry the sample in a vacuum concentrator for 1-min intervals until the tube appears dry.

54. Resuspend the sample in $20 \mu \mathrm{L}$ of Buffer EB. Vortex well. Repeat vortexing and centrifuging down several times to ensure that all of the precipitate has dissolved.

55. Run two replicates of $1 \mu \mathrm{L}$ of sample on an Agilent DNA 1000 chip. Record the size and concentration data for dilution.

56. Determine the DNA concentration using a Qubit/Quant-It dsDNA HS kit and measuring on a fluorometer.

57. If the DNA library appears acceptable, dilute it to $10 \mathrm{~nm}$ using a spreadsheet calculator and qPCR.

It is more important to have a clean library with a tight size distribution than excess DNA. The newer sequencers require fewer lanes to achieve complete whole-genome sequencing. 


\section{TBE Buffer}

Prepare a $5 \times$ stock solution in $1 \mathrm{~L}$ of $\mathrm{H}_{2} \mathrm{O}$ :

$54 \mathrm{~g}$ of Tris base

$27.5 \mathrm{~g}$ of boric acid

$20 \mathrm{~mL}$ of $0.5 \mathrm{M}$ EDTA (pH 8.0)

The $0.5 \times$ working solution is $45 \mathrm{~mm}$ Tris-borate $/ 1 \mathrm{~mm}$ EDTA. TBE is usually made and stored as a $5 \times$ or $10 \times$ stock solution. The $\mathrm{pH}$ of the concentrated stock buffer should be $\sim 8.3$. Dilute the concentrated stock buffer just before use and make the gel solution and the electrophoresis buffer from the same concentrated stock solution. Some investigators prefer to use more concentrated stock solutions of TBE ( $10 \times$ as opposed to $5 \times$ ). However, $5 \times$ stock solution is more stable because the solutes do not precipitate during storage. Passing the $5 \times$ or $10 \times$ buffer stocks through a 0.22 $\mu \mathrm{m}$ filter can prevent or delay formation of precipitates. 


\title{
Whole-Genome Sequencing: Manual Library Preparation
}

\author{
Elaine Mardis and W. Richard McCombie
}

Cold Spring Harb Protoc; doi: 10.1101/pdb.prot094615 originally published online November 1, 2016

\begin{tabular}{|c|c|}
\hline $\begin{array}{r}\text { Email Alerting } \\
\text { Service }\end{array}$ & Receive free email alerts when new articles cite this article - click here. \\
\hline $\begin{array}{l}\text { Subject } \\
\text { Categories }\end{array}$ & $\begin{array}{l}\text { Browse articles on similar topics from Cold Spring Harbor Protocols. } \\
\text { DNA Sequencing ( } 96 \text { articles) } \\
\text { Genomic DNA ( } 135 \text { articles) } \\
\text { Genomic Libraries (66 articles) } \\
\text { Libraries ( } 147 \text { articles) } \\
\text { Molecular Biology, general (1293 articles) }\end{array}$ \\
\hline
\end{tabular}

